\title{
PENGARUH TEKNOLOGI FAKTOR PRODUKSI TERHADAP PENINGKATAN USAHATANI JAGUNG
}

\author{
Asriani $^{1)}$, Sitti Rahma Ma’Mun ${ }^{2)}$ \\ ${ }^{1)}$ Fakultas Pertanian Universitas Muhammadiyah Kendari \\ Email: ${ }^{1)}$ asriani_umk@yaho.co.id
}

\begin{abstract}
ABSTRAK
Program pemerintah swasembada pangan perlu mendapat dukungan melalui peningkatan produktivitas komoditas pangan. Jagung merupakan salah satu tanaman pangan yang memiliki peranan strategis dan bernilai ekonomis serta mempunyai peluang untuk dikembangkan karena kedudukannya sebagai sumber utama karbohidrat dan protein setelah beras. Untuk meningkatkan produksi jagung dapat melalui peningkatan luas areal tanam dan peningkatan produktivitas tanaman jagung. Penelitian ini bertujuan untuk menganalisis faktor-faktor produksi yang dapat mempengaruhi produktivitas jagung di Indonesia. Data yang dipergunakan adalah data time series. Metode analisis yang digunakan adalah Partial Adjusment Model berupa persamaan tunggal regresi berganda dengan fungsi Natural Logaritma (Ln) dengan menggunakan teknik estimasi Ordinary Least Square (OLS). Hasil penelitian produksi jagung dipengaruhi oleh faktor harga jagung, harga pupuk, harga pestisida dan lag produktivitas.
\end{abstract}

Kata kunci: Produksi, jagung, Partial Adjusment Model,

\section{PENDAHULUAN}

Undang-undang pangan no. 18 tahun 2012 Kedaulatan pangan adalah hak negera dan bangsa secara mandiri menentukan kebijakan pangan yang menjamin hak atas pangan bagi rakyat dan yang memberikan hak bagi masyarakat untuk menentukan sistem pangan yang sesuai dengan potensi sumber daya lokal. Sedangkan katahan pangan adalah kondisi terpenuhinya pangan bagi negara sampai dengan perseorangan yang tercermin dari tersedianya pangan yang cukup, baik jumlah maupun mutunya, aman, beragam dan bergizi, merata dan terjangkau serta tidak bertentangan dengan agama, keyakinan, dan budaya masyarakat, untuk dapat hidup sehat, aktif dan produktif secara berkelanjutan. Sementara itu pengertian Kemandirian Pangan adalah kemampuan suatu negara dan bangsa dalam memproduksi pangan yang beraneka ragam dari dalam negeri yang dapat menjamin pemenuhan kebutuhan pangan yang cukup sampai di tingkat perseorangan dengan 
memanfaatkan potensi sumber daya alam, manusia, sosial, ekonomi dan kearifan lokal secara bermartabat. Proses transformasi sektor pertanian yang mampu menghasilkan produksi atau surplus pertanian di tingkat domestik dalam jumlah yang besar juga dianggap sebagai syarat pokok pertumbuhan ekonomi, pembangunan jati diri dan identitas suatu bangsa (Ditjen Tanaman Pangan, 2012)

Menurut Arifin, B. (2015) dalam Peningkatan kedaulatan pangan RPJM 2015 - 2019 kedaulatan pangan tercermin dari kekuatan untuk mengatur masalah pangan secara mandiri dapat didukung oleh a) ketahanan pangan, terutama kemampuan mencukupi pangan dari produksi dalam negeri b) pengaturan kebijakan pangan yang dirumuskan dan ditentukan oleh bangsa sendiri dan c) kemampuan melindungi dan mensejahterakan pelaku pangan terutama petani dan nelayan.

Sistem ketahanan pangan terdiri dari 3 (tiga) subsistem yaitu (1) sub sistem ketersediaan, yang berfungsi untuk menjamin pasokan pangan guna memenuhi kebutuhan seluruh penduduk dari segi kuantitas, kualitas, keragaman dan keamanannya (2) subsistem aksesibilita/distribusi, yang berperan untuk mewujudkan sistem distribusi yang efektif dan efisien sebagai prasyarat untuk menjamin untuk seluruh rumah tangga dapat memperoleh pangan dalam jumlah dan kuantitas yang cukup sepanjang waktu dengan harga yang terjangkau dan (3) subsistem konsumsi yang berfungsi untuk mengarahkan agar pola pemanfaatan pangan secara nasional dapat memenuhi kaidah mutu, keragaman, kandungan gizi, keamanan dan kehalalan disamping efisiensi untuk mencegah pemborosan (Yuwono, 2015)

Sektor pertanian secara umum terdiri dari beberapa sub sektor yaitu sektor pertanian pangan, hortikultura, dan perkebunan. Jagung merupakan salah satu komoditas sub sektor tanaman pangan pada sektor pertanian yang memiliki peranan sangat penting dalam perekonomian nasional setelah beras. Peranan jagung terhadap perekonomian nasional telah menempatkan jagung sebagai kontributor terbesar kedua terhadap Produk Domestik Bruto (PDB) setelah padi dalam subsektor tanaman pangan. Kondisi demikian mengindikasikan besarnya peranan jagung dalam memacu pertumbuhan subsektor tanaman pangan dan perekonomian nasional secara umum.

Jagung merupakan salah satu tanaman pangan yang memiliki peranan strategis dan bernilai ekonomis serta mempunyai peluang untuk dikembangkan karena kedudukannya sebagai sumber utama karbohidrat dan protein setelah beras (food), disamping itu juga jagung berperan sebagai bahan baku industri pakan (feed) dan bahan bakar nabati (biofuel). Dengan dikeluarkannya Perpres No. 5 Tahun 2006 Tentang Kebijakan Energi Nasional yang didukung dengan dikeluarkannya Inpres No. 1 Tahun 2006, peran sektor pangan menjadi 
semakin penting karena komoditi pangan pertanian juga berpotensi untuk menjadi bahan baku bahan bakar nabati (BBN) sebagai energi alternatif dimana pada tahun 2025 kontribusinya diharapkan diatas sebesar lima persen. Jagung merupakan salah satu komoditi yang potensial untuk menjadi bahan bakar nabati khususnya dalam bentuk bioetanol. Seiring dengan peranan jagung yang semakin meluas, maka kebutuhan jagung juga akan semakin besar. Hal tersebut harus diiringi dengan produksi (penawaran) yang semakin meningkat agar kebutuhan jagung dalam negeri dapat terpenuhi.

Indonesia pada 2010 memiliki ketersediaan lahan yang cocok ditanami jagung seluas 27 juta hektar, akan tetapi baru 3,7 juta hektar yang dimanfaatkan untuk ditanami jagung. Begitu juga dengan produktivitas jagung yang baru mencapai 4,44 ton/ha pada 2011, masih lebih rendah dibandingkan dengan potensi hasil varietas unggul yang mencapai 7-9 ton/ha. Jika potensi yang ada dimanfaatkan dengan maksimal, maka peluang Indonesia untuk mencapai swasembada jagung dan menjadi eksporter jagung dunia sangat terbuka seiring dengan semakin meningkatnya permintaan jagung, khususnya sebagai bahan baku pakan dan bahan bakar nabati (Badan Penelitian dan Pengembangan Pertanian Departemen Pertanian, 2012)

Beberapa penelitian tentang jagung di Indonesia dapat menghasilkan 10-11 t/ha, namum produktivitas di lahan petani sangat beragam, berkisar antara 3,2-8 t/ha (Girsang et al. 2010). Produktivitas jagung nasional pada tahun 2014 menurut data BPS adalah 4,8 t/ha. Secara empiris keragaman produktivitas jagung antarwilayah di Indonesia dan antarpetani disebabkan oleh perbedaan penerapan teknologi budi daya yang mencakup benih, varietas, pupuk, dan pengelolaan air. Di Indonesia wilayah tengah dan barat, usahatani jagung pada umumnya dilakukan secara komersil, menggunakan benih varietas hibrida, pupuk anorganik dan suplementasi pengairan pada musim kemarau. Akan tetapi di wilayah timur, jagung sebagian besar merupakan komponen usahatani subsistensi, menggunakan benih varietas lokal, pemupukan minimal atau pupuk organik dosis rendah dan sumber air sepenuhnya berasal dari hujan (Sutoro, 2015)

\section{Tujuan Penelitian}

Berkaitan dengan hal tersebut diatas, maka tujuan utama penelitian ini adalah: Mengetahui faktor-faktor yang mempengaruhi produktivitas komoditas jagung di Indonesia.

\section{METODE PENELITIAN}

\section{Jenis dan Sumber Data}

Data yang dipergunakan adalah data time series dari tahun 1980 sampai dengan tahun 2011. Permasalahan dalam penelitian ini menggunakan dua metode analisis yaitu melalui 
analisis kuantitatif dan analisis kualitatif. Analisis kuantitatif tersebut berupa analisis terhadap variabel-variabel utama atau faktor-faktor yang mempengaruhi respon penawaran komoditas jagung melalui fungsi respon produktivitas panen komoditas jagung dan produktivitas komoditas jagung.

\section{Metode Analisis Data}

Analisis respons penawaran komoditas jagung dalam penelitian ini menggunakan metode partial adjustment model (PAM) atau dikenal analisis model penyesuaian parsial Nerlove yang sering digunakan untuk studi mengenai respons penawaran berbagai komoditas berupa persamaan tunggal regresi berganda dengan fungsi natural logaritma atau logaritma natural (ln) ganda dengan menggunakan teknik estimasi ordinary least square (OLS). Pengolahan data meggunakan program eviews.

Hipotesis yang mendasari dalam memformulasikan model respon produktivitas komoditas jagung, yaitu:

1. Diduga harga jagung, lag produktivitas dan kebijakan pemerintah berpengaruh positif terhadap produktivitas komoditas jagung.

2. Diduga harga masukan (input) yaitu harga pupuk urea, harga pestisida akan berpengaruh negatif terhadap produktivitas komoditas jagung.

\section{Respon Produksi Secara Empiris}

Variabel-variabel yang dianggap relevan mempengaruhi produktivitas jagung adalah harga jagung, tingkat penerapan teknologi sebagai faktor utama dalam perubahan produktivitas yang tercernin dalam harga urea, harga pestisida, dan produktivitas tahun sebelumnya. Pada penelitian ini, harga jagung dan harga input yang digunakan sudah dirilkan.

Persamaan dari fungsi produktivitas jagung dapat dituliskan sebagai berikut:

$Y_{t}=f\left(H G_{t-1}, \operatorname{HPUK}_{t-1}, \operatorname{HPST}_{t-1}, Y_{t-1}, u_{t}\right)$

Dengan demikian model ekonometrik respon produktivitas jagung adalah:

$\mathrm{Y}_{\mathrm{t}}=\mathrm{d}_{0}+\mathrm{d}_{1} \mathrm{HJG}_{\mathrm{t}-1}+\mathrm{d}_{2} \mathrm{HPUK}_{\mathrm{t}-1}+\mathrm{d}_{3} \mathrm{HPST}_{\mathrm{t}-1}+\mathrm{d}_{4} \mathrm{Yt}-1+\mathrm{u}_{\mathrm{t}}$

Untuk mendapatkan nilai elastisitas dari peubah tak bebas terhadap peubah bebas, maka bentuk fungsi yang digunakan adalah fungsi logaritma natural. Sehingga fungsi respon areal panen:

Ln $\mathrm{Y}_{\mathrm{t}}=\mathrm{d}_{0}+\mathrm{d}_{1} \ln \mathrm{HJG}_{\mathrm{t}-1}+\mathrm{d}_{2} \ln \operatorname{HPUK}_{\mathrm{t}-1}+\mathrm{d}_{3} \ln \operatorname{HPST}_{\mathrm{t}-1}+\mathrm{d}_{4} \ln \mathrm{Y}_{\mathrm{t}-1}+\mathrm{u}$

Nilai yang diharapkan sebagai berikut:

$\mathrm{d}_{1}, \mathrm{~d}_{4},>0 ; \mathrm{d}_{2}, \mathrm{~d}_{3}<0$ 
Keterangan:

$Y_{t}$

: Produksi jagung pada tahun $\mathrm{t}(\mathrm{Ton} / \mathrm{ha})$,

$\mathrm{HJG}_{\mathrm{t}-1} \quad$ : Harga jagung pada tahun sebelumnya $(\mathrm{Rp} / \mathrm{kg})$,

HPUK $_{\mathrm{t}-1} \quad$ : Harga pupuk pada tahun sebelumnya $(\mathrm{Rp} / \mathrm{kg})$,

HPST $_{\mathrm{t}-1} \quad$ : Harga pestisida pada tahun sebelumnya $(\mathrm{Rp} / \mathrm{kg} ; \mathrm{Rp} / \mathrm{ltr})$,

$\mathrm{Y}_{\mathrm{t}-1} \quad$ : Produktivitas jagung pada tahun $\mathrm{t}-1$ (Ton/ha),

$\mathrm{u}_{\mathrm{t}} \quad$ : Galat pada tahun ke t.

\section{HASIL DAN PEMBAHASAN}

\section{Hasil Dugaan Respon Produksi}

Dari hasil estimasi respon Produksi jagung di Indonesia yang diperoleh pada table 2 dibawah, maka kemudian dilakukan pengujian secara ekonometrik untuk mengetahui apakah parameter yang diestimasi melakukan pelanggaran atau tidak terhadap asumsi klasik OLS. Dari ketiga uji ekonometrika, model respon produktivitas jagung di Indonesia sudah tidak mempunyai masalah dalam asumsi multikolinearitas, autokorelasi, dan heterokedastisitas. Hasil estimasi persamaan produktivitas jagung di Indonesia (Tabel 2)

Tabel 2 Hasil Estimasi Produktivitas Jagung di Indonesia

\begin{tabular}{llllll}
\hline Peubah Bebas & $\begin{array}{l}\text { Tanda } \\
\text { Harapan }\end{array}$ & Koefisien & $\begin{array}{l}\text { Standart } \\
\text { Error }\end{array}$ & t-statistik & P-value \\
& & -0.786 & 0.445 & -1.767 & $0.0899^{*}$ \\
\hline KONSTANTA & & 0.899 & 0.043 & 20.940 & $0.0000^{* * *}$ \\
$\mathrm{Y}_{\mathrm{t}-1}$ & + & 0.113 & 0.055 & 2.031 & $0.0535^{* *}$ \\
$\mathrm{HJG}_{\mathrm{t}-1}$ & + & 0.036 & 0.027 & 1.332 & 0.1952 \\
HPUK $_{\mathrm{t}-1}$ & - & -0.011 & 0.016 & -0.681 & 0.5027 \\
HPST $_{\mathrm{t}-1}$ & - & $\mathbf{0 . 9 9 4}$ & F-statistic & $\mathbf{6 9 8 . 1 5 5 * * *}$ \\
$\mathbf{R}^{\mathbf{2}}$ & & Tidak Ada & & \\
\hline Autokorelasi & & Tidak Ada & & \\
Multikolinieritas & & Tidak Ada & & \\
Heteroskedastisitas & & & & \\
\hline
\end{tabular}

Sumber : Data sekunder, diolah

Keterangan:

*** signifikan pada $\alpha=1 \%$

** $\quad$ signifikan pada $\alpha=5 \%$

* $\quad$ signifikan pada $\alpha=10 \%$ 
Pengujian masalah serial korelasi (autokorelasi) dalam fungsi respon produktivitas jagung dilakukan dengan menggunakan Breusch-Godfrey Serial Correlation LM Test dan dari hasil uji ini dapat dilihat bahwa probabilitas $O b s^{*} R$-squared-nya lebih besar dari taraf nyata 10 persen, yaitu sebesar 0,115 sehingga dapat disimpulkan bahwa model persamaan produktivitas jagung tidak mengalami masalah autokorelasi. Pengujian masalah heterokedastisitas dilakukan dengan menggunakan White Heteroscedasticity Test. Dari hasil uji ini tersebut dapat diketahui bahwa persamaan produktivitas mempunyai nilai probabilitas $O b s^{*} R$-squared-nya lebih besar dari taraf nyata 10 persen, yaitu sebesar 0,664 . Oleh karena itu dapat disimpulkan bahwa model produktivitas jagung tidak mengalami masalah heterokedastisitas. Pengujian terhadap multikolinearitas dengan menggunakan uji korelasi antar variabel bebas, dari uji tersebut memperli hatkan bahwa nilai-nilai koefisien determinasi parsial antara dua variable bebas, yang bila dibandingkan dengan koefisien determinasi (R-sq), dari hasil analisis diketahui bahwa nilai $R$-square dari peubah peubah tersebut masih lebih kecil dari $R$-square, sehingga dapat disimpulkan bahwa model maka persamaan produktivitas jagung tersebut tidak memiliki masalah multikolinearitas serius.

Berdasarkan hasil estimasi model produktivitas jagung di Indonesia yang tergambar dari Tabel. 2 di atas, dapat diketahui bahwa model respon produktivitas jagung di Indonesia mempunyai koefisien determinasi ( $R$-squared) sebesar 0.994 . Hal ini berarti bahwa variasi dari variabel independen yang masuk ke dalam model mampu menerangkan variabel dependen (produktivitas) sebesar 99,4 persen sedangkan sisanya dijelaskan oleh faktorfaktor di luar model.

Berdasarkan uji-F yang dilakukan terhadap respon produktivitas untuk melihat interval kepercayaan pada model, dapat diketahui bahwa variabel-variabel independen mampu menerangkan variabel dependen yang ditunjukkan oleh nilai probabilitas sebesar 0,0000 yang lebih kecil dari taraf nyata yang digunakan yaitu sebesar 10 persen $(\alpha=10 \%)$. Dari hasil tersebut dapat disimpulkan bahwa variabel-variabel yang dimasukkan dalam model secara bersama-sama mempengaruhi produktivitas jagung Indonesia secara nyata pada tingkat kepercayaan 99 persen.

Untuk mengetahui seberapa besar pengaruh variabel-variabel independen terhadap variabel dependen secara parsial maka digunakan uji t-statistik dapat dilihat pada (Tabel 5.2). Adapun hasil uji parsial faktor-faktor yang mempengaruhi peoduktivitas jagung di Indonesia adalah sebagai berikut:

1. Produktivitas jagung tahun lalu

Variabel lag produktivias berpengaruh signifikan pada tingkat kepercayaan 99 persen terhadap produktivitas jagung. Kenaikan 1 persen produktivitas tahun sebelumnya akan 
meningkatkan jumlah produktivitas 0,89 persen, cateries paribus. Pengaruh positif berarti Produktivitas jagung saat ini merupakan keberlanjutan produktivitas tanaman jagung sebelumnya, petani merespon dengan dengan meningkatkan produktivitas saat ini berdasarkan produktivitas tahun sebelumnya. Dengan menggunakan parameter ini pula, maka elastisitas jangka panjang dapat dihitung dan tanda koefisien variabel yang positif ini akan menjamin nilai elastisitas jangka panjang lebih besar dari nilai elastisitas jangka pendek.

2. Harga jagung

Variabel harga riil jagung tahun sebelumnya berpengaruh signifikan dengan tingkat kepercayaan 95 persen terhadap produktivitas jagung. Tanda positif yang berarti bahwa kenaikan harga jagung sebesar 1 persen akan meningkatkan produktivitas jagung sebesar 0,11 persen. Hal ini sesuai dengan teori yang ada dan rasionalitas petani dimana jika terjadi peningkatan harga jagung domestik maka akan ada tambahan insentif bagi petani, sehingga petani akan bertindak untuk menambah jumlah produksi jagung dengan cara meningkatkan produktivitas jagung dan mengoptimalkan pemakaian input produksi.

3. Harga Pupuk

Variabel harga pupuk urea memiliki tanda positif yang tidak sesuai dengan hipotesis dan tidak berpengaruh secara signifikan terhadap peningkatan produktivitas jagung. Pupuk urea merupakan pupuk utama yang dibutuhkan pada usahatani jagung, karena pupuk urea berperan penting terutama saat pertumbuhan tanaman jagung. Pupuk urea mengandung unsur Nitrogen $(\mathrm{N})$ yang merupakan unsur makro yang dibutuhkan oleh tanaman. Unsur makro merupakan unsur yang diperlukan tanaman dalam jumlah yang besar dan apabila tanaman jagung kekurangan unsur ini maka akan mengalami gejala defisiensi pada tanaman tersebut. Oleh sebab itu, unsur ini sulit atau tidak bisa digantikan dengan unsur hara yang lain. Jumlah takaran pemakaian pupuk urea untuk memperoleh hasil maksimal adalah 200-300 kg/ha, dimana pada saat tanam, jumlah pupuk urea yang diberikan sebesar 90-120 kg/ha dan sepanjang pemeliharaan diperlukan pupuk urea sebesar 100$200 \mathrm{~kg} / \mathrm{ha}$. Oleh karena itu, meskipun harga pupuk urea meningkat, pupuk ini harus tetap digunakan oleh petani. Di samping itu, keberadaan pupuk urea selama ini masih disubsidi oleh pemerintah, sehingga jika terjadi kenaikan harga urea petani masih bisa membeli dan menggunakan pupuk ini. Hasil analisis ini juga sejalan dengan temuan Puteri (2009) bahwa harga pupuk urea berhubungan positif terhadap produktivitas.

\section{Harga Pestisida}

Variabel harga riil pestisida meskipun tidak secara signifikan tapi berpengaruh negatif terhadap produktivitas jagung. Variabel pestisida tidak bepengaruh signifikan 
disebabkan karena saat ini petani jagung masih banyak menerapkan cara tradisional untuk mengedalikan hama dan penyakit, karena jagung merupakan salah satu tanaman yang mempunyai sedikit resiko dalam serangan organisme pengganngu tanaman, ditambah lagi penggunaan bibit unggul dan komposit yang tahan terhadap hama dan penyakit, sehingga pestisida tidak terlalu banyak dibutuhkan oleh petani jagung.

\section{KESIMPULAN}

Berdasarkan hasil penelitian dapat disimpulkan beberapa hal sebagai berikut:

Faktor harga jagung, harga upuk, harga pestisida dan lag produktivitas pengaruh terhadap jagung di Indonesia. Faktor produksi tersebut merupakan faktor yang dapat dilakukan melalui program intensifikasi yakni peningkatan produksi melalui perbaikan teknologi dalam rangka mewujudkan swasembada pangan berkelanjutan.

\section{DAFTAR PUSTAKA}

Arifin, B. (2015). Pembangunan Kedaulatan Pangan Berbasis Sumberdaya Lokal. Seminar

Nasional Perhepi Komda Kendari dan Jurusan Agribisnis Universitas Haluoleo. Kendari

BPS. (2017). Statistik Indonesia. Biro Pusat Statistik. Jakarta.

Direktorat Jenderal Tanaman Pangan. (2011). Road Map Pencapaian Sasaran Produksi Jagung 2012-2014. Departemen Pertanian. Jakarta.

Gujarati, D. (1995). Basic Econometrics. Third Edition, Mc-Graw-Hill International Edition. New York, USA.

Girsang, S.S., M.P. Yufdy, and Akmal. (2010). Fertilizer recommendation based on the SSNM approach in upland Karo district, North Sumatera. p.540-544. In: P.H. Zaidi, M. Azrai, and K. Pixley (eds.): Maize for Asia. Proc. of the 10th Asian Regional Maize Workshop.Ministry of Agriculture (Indonesia), CIMMYT, ADB and S.M. Sehgal Foundation.IAARD. Jakarta.

Koutsoyianis, A.(1977). Theory of Econometrics. Second Edition. The Macmillan Press, New York.

Nerlove, M. (1958). The dynamics of supply : Estimation of Farmers Response to Price. The Johns Hopkins Press, Baltimore. USA.

Puteri, G. (2009). Analisis Respon dan Proyeksi Penawaran Ubi Kayu di Indonesia. Fakultas Ekonomi dan Manajemen Institut Pertanian Bogor. Bogor 
Sutoro, (2015). Determinan Agronomis Produktivitas Jagung. Jurnal Iptek Tanaman Pangan Vol 10 (1) 2015

Widarjono, A . (2009). Ekonometrika : Pengantar dan Aplikasinya. Ekonesia Fakulatas Ekonomi UII, Yogyakarta

Yuwono, B. (2015). Analisis Kemandirian Pangan Berbasis Sumberdaya Lokal di Provinsi Sulawesi Tenggara. Seminar Nasional Perhepi Komda Kendari dan Jurusan Agribisnis Universitas Halu Oleo. Kendari 